\title{
PHYTOPHARMACOLOGY OF AN IMPORTANT UNANI DRUG BAZR-UL-BANJ (HYOSCYAMUS NIGER LINN.) - REVIEW
}

\author{
MISBAHUDDIN AZHAR ${ }^{1 *}$, MUSTEHASAN $^{2}$ \\ ${ }^{1}$ Regional Research Institute of Unani Medicine, Shahjahan Manzil, Near AMU Riding Club, Aligarh. ${ }^{2}$ Central Council for Research in Unani \\ Medicine, Janakpuri, New Delhi, India. Email: ccrum619@gmail.com \\ Received: 05 May 2020, Revised and Accepted: 29 July 2020
}

\section{ABSTRACT}

Objective: Bazr-ul-Banj syn. Ajwain khurasani (Hyoscyamus niger Linn.) is one of the important drug mentioned in Unani literature. It mentioned by the great Unani philosopher Dioscorides (first century AD) in his treatise Kitab-al-Hashaish. According to Unani philosophy, Bazr-ul-Banj is in third-degree category according to its temperamental nature. H. niger Linn. contains tropane alkaloids in good quantity, mainly hyoscyamine and scopolamine.

Methods: Unani classical literature was searched from recent to past available in different libraries. For phytochemistry, pharmacology, and clinical studies to prove, the importance computerized databases such as Medline, PubMed, Ovid SP, Google Scholar, and Science-direct were searched. All the information of plant available in Urdu, Persian, Arabic, and studies published abstract were included in the study.

Results: Fourteen Unani books were referred and 18 pharmacological studies were recognized. The action of Bazr-ul-Banj mentioned in Unani classical literature are Hazim (Digestive), Mudammil (Cicatrizant), Mujaffif (Dessicant), Mukhaddir (Anesthetic), Munashshi (Narcotic), Munawwim (Hypnotic), Musakkin (Sedative), Musakkin-e-Alam (Analgesic), Raade (divertive), Qabiz (Astringent), etc., and useful in Amraz-e-asbania (nervous affections), Amraz-e-Raham (uterine spasm and pain), Dard wa Alam (pain), Ikhtelaj-e-Qalb (palpitation), Junoon (mania), Niqras (Gout), Zeequn Nafas (Bronchial asthma), etc. H. niger Linn. showed many pharmacological effects included antimicrobial, anticancer, analgesic, anti-inflammatory, antipyretic, antihypertensive, and antidiarrheal activities in different clinical and experimental studies.

Conclusion: This presentation is an attempt to showcase the action, uses mentioned in Unani literature, chemical constituent, and pharmacological and toxicological effects at one place. It may also observe that the drug is having many actions which may be beneficial in cases of COVID-19. It may be concluded this should be tested as adjuvant medicine in cases of COVID-19.

Keywords: Ajwain khurasani, Bazr-ul-Banj, Hyoscyamus niger Linn., Unani medicine.

(C) 2020 The Authors. Published by Innovare Academic Sciences Pvt Ltd. This is an open access article under the CC BY license (http://creativecommons. org/licenses/by/4. 0/) DOI: http://dx.doi.org/10.22159/ajpcr.2020.v13i9.38166

\section{INTRODUCTION}

Unani system of medicine (USM) is one of the oldest systems of medicine based on Hippocratic theory of Akhlat-e-arba (four humors). In this system the drugs are used from three sources, plant, animal, and minerals origin; however, the main source is plants and their products. According to the World Health Organization presently, $80 \%$ of the world population depends on herbal medicine for some aspect of primary health care. However, plants still provide some of our most valuable medicines [1-15].

Bazr-ul-Banj (Hyoscyamus niger Linn.) [16] is a native of Himalaya, but in use since a long time in USM. Dioscorides (first century AD) the great Unani physician and philosopher has mentioned the preparation of a sun-dried extract from the juice of the fresh whole plants or seeds is useful for the treatment of sleeplessness and pain [17]. He says that the dried aqras (pills) prepared from the extract pounded with flour, can retain their medicinal properties for 1 year [18]. Probably, the ancient ayurvedic physicians were not aware of it. It was introduced to India during $9^{\text {th }}$ century [19]. Henbane is literally translate "Hen Killer" [20] and its name derived from the anglo-saxon (hen (chicken) and bana (Murderer) because when fowls eat its seeds, they become paralyze and die [21]. It grows in two distinct forms annual and biennial. Stem is simple thick and about $0.5 \mathrm{~m}$ high leaves are dark in color, hairy with an irregular border, the fruits like that of pomegranate full of seeds resembling poppy seeds. Flowering time is during July and August corolla is paler in color and deeply veined. It is also found in Europe, Sabaria, Egypt, and Iran. Its taste is bitter. Unani scholars describe its three varieties according to color of its flowers, for example, white, black, and red. White flower is considered best for medicinal purposes. Extract of henbane seed, leaves, and root are used by some witches to run or fly on fire and when thieves come to rub them [22]. It is toxic plant exposure to potentially either intentionally or accidentally could induce toxic manifestation [23-25]. Nearly 900 patients during 19811991 were referred to the poison center of Imam Reza of Mashhad of Iran due to its poisoning [26,27].

\section{METHODS}

Unani classical literature was searched from recent to past available in different libraries. For phytochemical, pharmacological activities, and clinical trials carried out to prove the importance of Bazr-ul-Banj (H. niger Linn.), computerized databases such as Medline, PubMed, Ovid SP, Google Scholar, and Science-direct were searched. All the information of plant available in Urdu, Persian, Arabic, and studies published abstract were included in the study. Fourteen Unani books were referred and 18 pharmacological studies were recognized.

\section{Taxonomic classification}

Kingdom: Plantae

Division: Tracheophyta

Subdivision: Spermatophytina

Class: Magnoliopsida

Family: Solanaceae

Genus: Hyoscyamus

Species: Hyoscyamus albus, H. niger, and Hyoscyamus reticulates. 


\section{Temperament}

The USM describes the general character of a drug in terms of its temperament. According to Unani philosophy, drugs are classified as per the specific temperament (Mizāj) and are graded in the first, second, third, and fourth-degree according to their potency. According to this philosophy of Unani system, Bazr-ul-Banj is cold and dry in the third degree of temperament [28-35].

\section{Part used}

As per Unani classical literature, seeds and leaves are used for various therapeutic purposes.

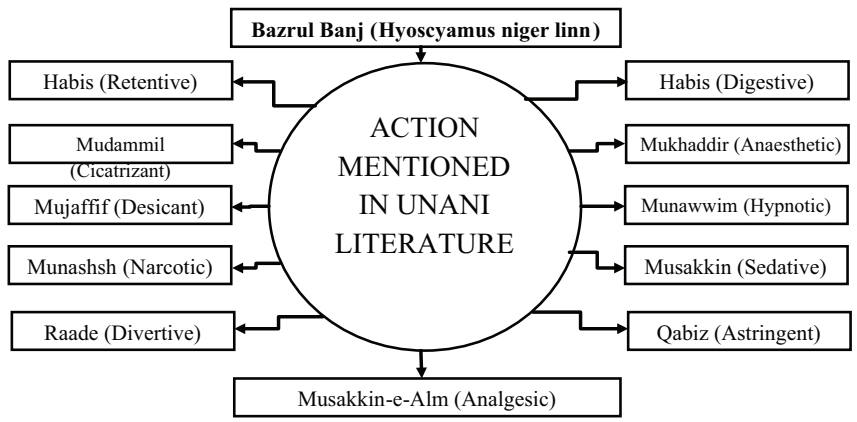

\section{Action}

Unani scholars mentioned it action as: Habis (Retentive) [28,29,31,32,35-41]; Hazim (Digestive) [31,36]; Mudammil (Cicatrizant) [31]; Mujaffif (Dessicant) [32,36,37]; Mukhaddir (Anesthetic) [29,31,35,37,38,41]; Munashshi (Narcotic) [28,31,36]; Munawwim (hypnotic) [28-35,37-39,41]; Musakkin (Sedative) [28,29,32-41]; Musakkin-e-Alam (Analgesic) [29,31,32]; Raade (divertive) [29,35-38,41]; and Qabiz (Astringent) [31,32,36].

\section{Potent action}

The potent action of this plant is Musakkin (sedative) [29,35].

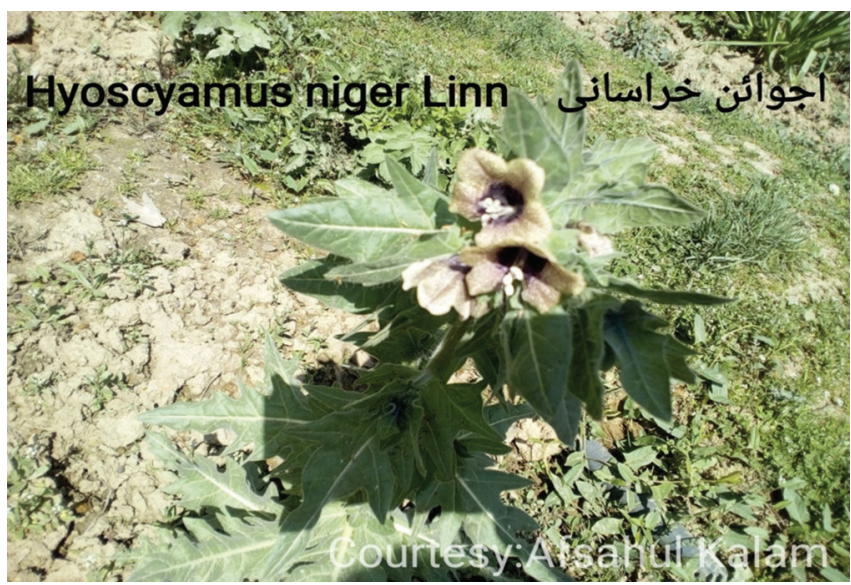

\section{Uses}

It is useful in Amraz-e-asbania (nervous affections) [28,29,31,32]; Amraz-e-Raham (Uterine spasm and pain) [28,31,32,37,40]; Asbi dard (neuralgia) [28,31,32]; Bars (Vitiligo) [40]; Bawaseer (hemorrhoids) [31]; Dard wa Alam (pain) [28,31,32,35,37,39]; Epiphora [28,31,32,34,39,41]; Fuwaq (Hiccup) [27,31,32]; Ikhtelaje-Qalb (palpitation) [28,31,32]; Iltihab/warm (inflammation) [28,31,32,34,37,39]; Irqun Nisa (sciatica) [31,37,39,41]; Jirayanud-dam (hemorrhage) [31,35,38,41]; Junoon (mania) [31,35,41]; Kharish (Pruritis) [31]; Malikholia (Melancholia) [31]; Nafsud dam (hemoptysis) [28,31,32,37,39,41]; Nazla (Catarrh) [28,31,41]; Niqras (Gout) [31,35,37-39,41]; Nisyan e Muzmin (Ch. Dementia) [28,31,32,41]; Quolanj (Colic) [31]; Qurooh-e-Raham (uterine ulcers) [31]; Sahr (insomnia) [31,41]; Sailan-ur-reham (leucorrhoea) [28,31,32,34,37,39]; Shahiqa (whooping cough)
[28,31,41]; Suda (Cephalgia) [28,31-34,37,39]; Waja-ul Asnan (Toothache) [28,31,32,34,35,37-39,41]; Waja-ul Mafasil (poly arthritis) [31,35,37,39,41]; Waja-ul Meda (gastralgia) [31]; Waja-ul Uzn (otalgia) [28,31,32,34,35,37,39,41]; Warm-e-Khusyatein (Orchitis) [28,31,37]; Warm-e-Hanjara (Laryngitis) [28,31,37]; Warm-e-Pistan (Mastitis) [28,31,37]; and Zeequn Nafas (Bronchial asthma) [28,29,31,35].

\section{Ethnopharmacology action}

In ethnobotanical books, the action of the plants is mentioned as: Antiinflammatory $[19,42]$; antispasmodic $[42,43]$; intoxicating $[19,43]$; anesthetic [16]; narcotic $[18,43,44]$; hypnotic $[18,43,44]$; sedative $[18,43,44]$; analgesic [18,19,42-45]; mydriatic [42-46]; and astringent [42-44]

\section{Ethnomedicinal uses}

Thisplantmaybeusedinvariousdisease, thatis, nervousdisorders [18,44]; uterine spasm $[18,19,42,44]$; uterine pain $[18,19,42,44]$; neuralgia [19,43-45]; epiphora [19,43,44]; hiccup [19,43]; functional palpitation $[19,43]$; inflammation $[19,43,44]$; mania $[19,43]$; locomotor alexia [18,44]; melancholia [19,43]; maniacal excitement $[19,43,46]$; hemoptysis [44]; catarrh [42-45]; chronic dementia [19,43]; insomnia $[19,43]$; leucorrhoea $[19,43,44]$; whooping cough [42-45]; cephalgia $[19,43,44]$; toothache $[19,43,44]$; otalgia $[19,42,44]$; orchitis $[19,42-44]$; laryngitis [43]; mastitis [19,42-44]; and asthma [19,42-45].

\section{Dose}

In Unani classical text, the dose of Bazr-ul-Banj is mentioned 500-750 mg [31,35,41]

\section{Substitute}

In Unani classics, it is also refer that in case of non-availability of the drug substitute may be used. It is stated that Afiyun (Papaver somniferum); Balchar (Nardostachyas jatamansi); Luffah (Atropa belladonna); and Tukhme-Karafs (Apium graveolens) [31,32] may be used.

\section{Corrective}

To counter any adverse effect of drug, some corrective measure may be adopted. For this Shahad (Honey) [35] Ghee (Clarified butter), Doodh (Milk), Khaskhash (P. somniferum), Anisoon (Pimpinella anisum), and Milk of sheep [30,31] may be used along with the drug to avoid any adverse reaction.

\section{Chemical constituents}

H. niger seeds were reported to contain alkaloid (hyoscyamine, hyoscine, scopolamine, atropine, etc.) $[22,47,48]$, volatile oil, glycoside, mucilage, albumin, steroidal glycosides (atroposide A, atroposide C, atroposide E, and petunia side L), phenolics, (vanillic acid, vanillin, pinoresinol, and $\mathrm{N}$ trans-feruloyl tyramine), and phytosterols (daucosterol and betasitosterol), etc. $[49,50]$.

\section{Pharmacological studies}

Many pharmacological studies were conducted on the plant in different experimental models. These pharmacological activities are alphabetically arranged here.

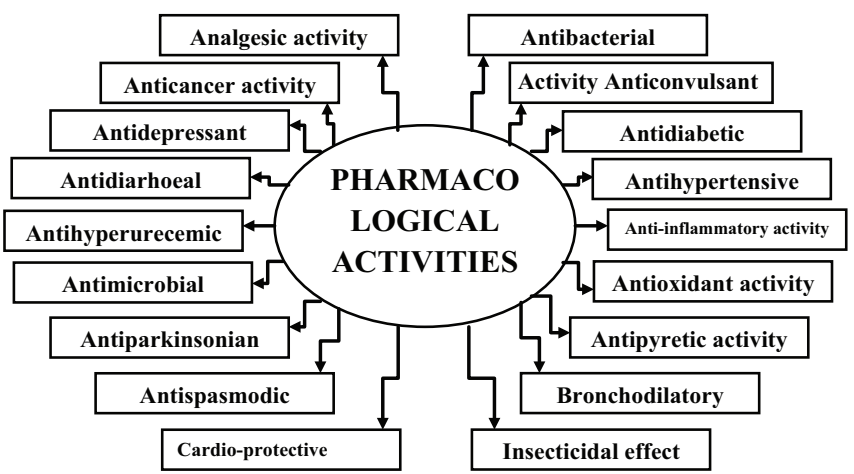




\section{Analgesic activity}

The methanolic extract of seeds of $H$. niger and leaves of $H$. albus showed analgesic activity in experimental animal models at different doses in hot plate reaction time and writhing response [51-53]. Hydroalcoholic extract of seeds decreased the formalin-induced acute and chronic pain significantly through parental and oral route relative to the control group [54,55]. Methanolic extract of $\mathrm{H}$. reticulatus $\mathrm{L}$. possesses a significant antinociceptive activity in both central and peripheral pain models in mice [56]. The crude extract of $H$. niger reduced the numbers of acetic acid-mediated writhes in mice in dosedependent manner [57].

\section{Antibacterial activity}

Alkaloidal extract showed antibacterial activity against microorganisms: Pseudomonas stutzeri, Staphylococcus aureus, Escherichia coli, and Klebsiella pneumonia [58].

\section{Anticancer activity}

Alkaloidal extract showed anticancer activity by reducing the spontaneous frequency of chromosomal aberrations, micronuclei assay, and increased the mitotic index in mice bone marrow cells. Alkaloidal extract also induced apoptosis activity rather than cytotoxic activity against cancer cell lines (A549, PC-3) [27]. Compounds grossamide, and cannabisins $\mathrm{D}$, and $\mathrm{G}$ isolated from $\mathrm{H}$. niger seeds exhibited moderate cytotoxicity in cultured LNCaP human prostate cancer cells [59].

\section{Anticonvulsant activity}

Methanolic extract of $H$. niger L. possess the anticonvulsant activity against picrotoxin-induced seizures in mice by increasing latency and duration of seizure also delayed the death as compared to control [60]. Alcoholic seed extract of $H$. niger has markedly alleviated pentylenetetrazol-induced seizure phases in male mice [61].

\section{Antidepressant effect}

$H$. niger leaves ethanolic extract significantly reduced immobility duration of mice in forced swim test and tail suspension test in higher dose; it also showed anxiolytic activity [62].

\section{Antidiabetic activity}

Calystegines, polyhydroxylated alkaloids extracted from H. albus seeds showed antidiabetic effect on streptozotocin-induced diabetes in mice by markedly reducing blood glucose levels and minimized damages on $\beta$-cells of islets of Langerhans, also stimulated $\beta$-cells regeneration, and improved insulin secretion [63]. The oral administration of methanolic extract of leaves of $H$. albus significantly reduced the levels of blood glucose and glycosylated hemoglobin in streptozotocin-induced diabetic rats [64].

\section{Antidiarrheal activity}

The crude extract of $H$. niger seeds exhibited antidiarrheal and antisecretory effects against castor oil-induced diarrhea and intestinal fluid accumulation in mice [65].

\section{Antihypertensive}

H. niger crude extract lowers blood pressure through a $\mathrm{Ca}(++)-$ antagonist mechanism in dose-dependent manner in rats and guinea pig models, also exhibited a cardio depressant effect on the rate and force of spontaneous atrial contractions [66].

\section{Antihyperuricemic activity}

Aqueous extract showed an inhibitory effect on xanthine oxidase activity, oral administration of the aqueous extract significantly reduced serum urate levels in hyperuricemia induced in mice in a dosedependent manner $[67,68]$.

\section{Anti-inflammatory activity}

The methanolic extract of seeds of $H$. niger showed an anti-inflammatory effect in carrageenin-induced paw edema and cotton pellet granuloma methods [51].

\section{Antimicrobial activity}

The butanolic extract of $H$. albus possessed antibacterial effects against S. aureus, E. coli, P. stutzeri, Pseudomonas aeruginosa, Proteus mirabilis, and $K$. pneumonia $[58,69,70]$. The methanol extracts of the seeds of $H$. niger showed antimicrobial effect against urinary tract pathogens (Enterococcus faecalis, E. coli, K. pneumoniae, P. aeruginosa, P. mirabilis, and Candida albicans) [71-73].

\section{Antioxidant activity}

Aqueous methanol extract significantly inhibited monoamine oxidase activity and attenuated 1-methyl-4-phenyl pyridinium (MPP+)induced hydroxyl radical $(\cdot \mathrm{OH})$ generation in isolated mitochondria [67,69,70,74]. Methanolic extracts of $H$. albus exhibited maximum 2, 2-diphenyl-1-picrylhydrazyl (DPPH) antiradical, nitric oxide scavenging, and metal chelating activities [75] compared to $\alpha$-tocopherol $[67,76]$. Aerial parts of $H$. niger extract exhibit DPPH and ferric, reducing antioxidant scavenging properties [77]. Hexane and water extracts of $H$. reticulates showed radical scavenging, antioxidant capacity, ferric, and cupric reducing powers [78].

\section{Antiparkinsonian}

Aqueous methanol extracts of $H$. niger seeds significantly attenuated motor disabilities (akinesia, catalepsy, and reduced swim score) and striatal dopamine loss in -methyl-4-phenyl-1,2,3,6-tetrahydropyridine treated mice [74] and also against the stereotaxically induced rotenone model of Parkinson's disease in rats due to antioxidant activity [79].

\section{Antipyretic activity}

H. albus methanolic extract showed a dose-dependent lowering effect of the body temperature up to $3 \mathrm{~h}$ in comparable to paracetamol $[52,53]$. Methanolic extract of seeds of $\mathrm{H}$. niger exhibited antipyretic activity in yeast-induced pyrexia model [51].

\section{Antispasmodic activity}

The crude extract of $H$. niger seeds inhibited contractions induced by carbachol and potassium in a pattern similar to that of dicyclomine, but different from verapamil and atropine [65].

\section{Bronchodilatory effect}

The crude extract of H. niger exhibits airways relaxation, inhibition of the CCh-induced increase in the inspiratory pressure of anesthetized rats [57].

\section{Cardioprotective activity}

Oral administration of crude powder of the H. niger protected rats from the cardiac damage induced by lipid peroxidation and activation of antioxidant enzymes. It protected from cardiac necrosis as evidenced by the inhibitory activity on CK-Mb and TGL [80].

\section{Insecticidal effect}

Methanol extract of aerial parts and flower of $H$. niger had destroyed the mosquitoes Anopheles spp. larvae [81].

\section{Contraindicated and adverse effect}

Bazr-ul-Banj has an adverse effect on the brain as daur ul raas (vertigo), Sadr (Giddiness), Khunaq (Diphtheria), Junoon (Mania) [27,28,45]. Ingestion of Bazr-ul-Banj by patients with medical underlying problems such as Down syndrome, narrow-angle glaucoma, cardiac disease, pregnancy, and breast-feeding needs more attention fatalities were reported in children [26,82-85].

\section{Unani formulations}

According to USM, the choice of drugs for treatment is governed by three laws: (i) Quality of drug in terms of temperament, (ii) quantity of drug in terms of its weight and potency, and (iii) time of administration. The selection of drug depends on the nature and type of the disease. To achieve the target, single and compound formulations were prescribed. The Unani Drugs are being manufactured mostly in the classical form. Modern instruments are used in the preparation of drugs. Sometimes, 
minor alterations are made in the dosage forms, and due care is taken not to depart from the essence. The Unani Drug Industry is preparing and marketing two types of drugs: (i) Classical Unani formulations and (ii) patent and proprietary products. Good manufacturing practices are followed to ensure quality control of these drugs. Some important classical Unani formulations in which Ajwain khurasani is one of the ingredients mentioned in National Formulary of Unani Medicine.

\begin{tabular}{|c|c|c|}
\hline Banadiqul Bazoor [86] & Habbe Jadwar [86] & Habb-e-Tinkar [86] \\
\hline Tiryaq-e-Nazla [86] & $\begin{array}{l}\text { Qurs } \\
\text { Mukhaddir [86] }\end{array}$ & Qurs Musallas [86] \\
\hline Safoof Moya [86] & Barshasha [86] & Habb-e-Jazla [86] \\
\hline Habb-e-Rasha [86] & $\begin{array}{l}\text { Habb-e- } \\
\text { Shingraf [86] }\end{array}$ & Habb-e-Sultani [87] \\
\hline $\begin{array}{l}\text { Qurs Khashkhas [87] } \\
\text { Jawarish Shahinshahi }\end{array}$ & $\begin{array}{l}\text { Habb-e-Aswad [87] } \\
\text { Habb-e-Jiryan [88] }\end{array}$ & $\begin{array}{l}\text { Majoon Kakanaj [87] } \\
\text { Habb-e- }\end{array}$ \\
\hline $\begin{array}{l}\text { Ambri [87] } \\
\text { Lauq bazr-ul banj [88] }\end{array}$ & $\begin{array}{l}\text { Roughan Bazr-ul- } \\
\text { Banj [89] }\end{array}$ & Muqawwi [88] \\
\hline
\end{tabular}

\section{CONCLUSION}

The present review emphasizes the action and uses mentioned in Unani classical literature, ethnopharmacological, photochemistry, pharmacological reports, and toxicological information of Bazr-ulBanj (H. niger Linn.). It may be concluded that many pharmacological reports proved the claims of Unani scholar's, for example, Musakkin-eAlam [29,31,32] (Analgesic) [51-57], Iltihab/warm [28,31,32,34,37,39] (inflammation) [51]; Ikhtelaj-e-Qalb [28,31,32] (cardioprotective) [80,81]; Zeequn Nafas [28,29,31,35] (Bronchodilatory) [57], etc., many more action mentioned in Unani literature are required still proved. It is suggested that the results of experimental studies may be taking up forward for clinical safety and efficacy studies at a large sample size. It may also be observed that important Unani herb is having analgesic, antipyretic, anti-inflammatory, bronchodilator [51-57], antidiarrheal [65], antimicrobial [71-73], antioxidant [69-78], cardioprotective [80], and all these activities are required to treat COVID-19 cases. It may also be recommended that scientific community should take up the job and try this Unani drug in cases of COVID-19 as an adjuvant therapy along with the contemporary treatment. This review also guides to the scientist working in different fields of medicine, photochemistry, pharmacology may take up the steps to establish the efficacy of Bazr-ul banj in better way for the services in mankind in the future.

\section{ACKNOWLEDGMENT}

The authors are thankful to Prof. Asim Ali Khan, Director General, Central Council for Research in Unani Medicine, New Delhi, for providing a good atmosphere for research in the council.

\section{AUTHORS' CONTRIBUTIONS}

The authors were actively searched the data on the topic from libraries of council and other Unani colleges and internet and equally contributed to the preparation of this manuscript.

\section{CONFLICTS OF INTEREST}

The author has no conflicts of interest to share.

\section{AUTHORS' FUNDING}

The author received no specific funding for this work from any agency.

\section{REFERENCES}

1. Azhar MU, Khanam D, Aslam M, Tajuddin, Jafri MA. Plants with nephrotoxic activity. J Sci Pharm 2004;5:97-103.

2. Azhar MU, Javed K, Jafri MA. Plant with nephroprotective activity. Hamdard Med 2005;48:33-43

3. Azhar MU, Akhtar F, Aslam M, Anwar M, Tajuddin, Jafri MA, Nephroprotective activity of some herbal preparations. Hamdard Med 2005;49:110-5

4. Azhar MU, Quddusi N, Anjum N, Akhtar J, Hannan A, Jamil SS. Care of skin through Unani system of medicine. Unimed Kulliyat 2009;4:9-12.

5. Azhar MU, Quddusi N, Parveen S, Tajuddin, Siddiqui KM, Siddiqui MK. Daa-us-sadaf (psoriasis) and role of herbal drugs. Hamdard Med 2010;53:51-7.

6. Azhar MU, Quddusi N, Akhtar J, Akram U, Anjum N, Hannan A. Pharmacologial activities of Shilajit (asphaltum)-a Unani drug. Indian J Unani Med 2011:4:5-8.

7. Azhar MU, Akhtar J, Akram U, Anjum N, Quddusi N. Pharmacological activity of holy drug-zaitoon (Olea europaea linn.)-review. Indian J Unani Med 2011;4:85-91.

8. Azhar MU, Anjum N, Quddusi N, Akhtar J, Akram U, Yadav PK. Pharmacologically active nephroprotective plants-a review. Hamdard Med 2013;56:56-76.

9. Azhar MU, Anjum N, Quddusi N. Pharmacological activity of khurma (Phoenix dactilifera Linn.). A review. Hamdard Med 2015;58:71-83.

10. Azhar MU, Anjum N, Quddusi N. Pharmacologically active cardioprotective plants at a glance. Hamdard Med 2015;58:51-83.

11. Akram M, Azhar MU. Revend (rhubarb): An important Unani drug for prevention of nephrotoxicity. Int J Pharm Prof Res 2016;7:1333-40.

12. Anjum N, Quddusi N, Azhar MU. Phytopharmacological aspects of bisehri booti (Aerva lanata) and its uses in Unani system of medicine-a review. Hippocratic J Unani Med 2017;12:51-64.

13. Azhar MU, Anjum N. Revand chini (Chinese rhubarb): A review on historical and Unani classical prospect. Int J Unani Integr Med 2019;3:11-8

14. Akram M, Azhar MU, Anjum N, Quddusi N. Phytopharmacology of Unani drug Zeerah siyah (Carum carvi linn)-a review. J Pharmacogn Phytochem 2019;8:2772-82

15. Azhar MU, Mustehasan, Alam M, Ahmad SG, Anjum N, Quddusi N. Nephroprotective Unani drug khare-khasak khurd (Tribulus terrestris linn.)-a review. Int J Sci Res Biol Sci 2020;7:24-36.

16. Anonymous. The Wealth of India: A Dictionary of Raw Materials and Industrial Products, Raw Materials. Vol. 5. New Delhi: Publications and Information Directorate; 1997. p. 151-4.

17. Hocking GM. Henbane-healing herb of Hercules and of Appollo. Econ Bot 1947; 1:306-16.

18. Bentley R, Trimen H. Medicinal Plants. London: J \& A Churchill; 1880. p. 121.

19. Dymock W, Warden CJ, Hopper D. Pharmacographia Indica. Vol. 2. Dehradun: M/S Bishen Singh Mahendra Pal Singh; 1976. p. 313.

20. Volak J, Stodola J. The Illustrated Book of Herbs: Their Medicinal and Culinary Uses. London: Chancellor Press, Bounty Books; 1992.

21. Haas LF. Hyoscyamus niger (Henbane). J Neurol Neurosurg Psychiatry 1995;59:114

22. Paulsen BP. Highlights through the history of plant medicine. In: Bernhoft A, editor. Bioactive Compounds in Plants-Benefits and Risks for Man and Animals. Oslo: Proceeding from a Symposium Held at the Norwegian Academy of Science and Letters; 2010.

23. Oztekin-Mat A. Plant poisoning cases in Turkey. Ann Pharm Fr 1994;52:260-5.

24. Fuchs J, Rauber-Luthy C, Kupferschmidt H, Kupper J, KullakUblick GA, Ceschi A. Acute plant poisoning: Analysis of clinical features and circumstances of exposure. Clin Toxicol (Phila) 2011;49:671-80.

25. Moshiri M, Etemad L, Javidi S, Alizadeh A. Peganum harmala intoxication, a case report. Avicenna J Phytomed 2013;3:288-92.

26. Daneshvar S, Mirhossaini ME, Balali-Mood M. Hyoscyamus poisoning in Mashhad. Toxicon 1992;30:501.

27. Al-Snafi AE. Therapeutic importance of Hyoscyamus species grown in Iraq (Hyoscyamus albus, Hyoscyamus niger and Hyoscyamus reticulates)-a review. IOSR J Pharm 2018;8:18-32.

28. Ibn Baitar ZU. Kitab-al-Jami-ul-Mufradat-al Adwia-wal Aghzia. Vol. 1. New Delhi: Central council for Research in Unani Medicine Publication; 1985. p. 293-7.

29. Rafiquddin M. Kunzul Advia Mufrada. Aligarh: Aligarh Muslim University, University Publication Unit; 1985. p. 163-6.

30. Aziz MA. Mufradat-e-Azizi. Lucknow: Sahitya Mandir Press Ltd.; 1948. p. 5.

31. Ghani MN. Khazinatul Advia. Vol. 3. Lahore: Barqi Press; 1917. p. 21-5.

32. Hakeem MA. Bustan-ul-Mufradat. Lucknow: Taraqqi Urdu Publication; 1894. p. 54.

33. Kareem NA. Makhzanul Advia. Vol. 2. Kanpur: Munshi Nawal Kishore; 1888. p. 99

34. Majoosi AA. Kamil-us-Sana. (Urdu Translation by Ghulam H Kantoori). Vol. 2. Lucknow: Munshi Nawal Kishore; 1889. p. 137.

35. Kabiruddin M. Makhzan-ul-Mufradat. Vol. 1. Hyderabad: National Fine Printing Press; 1955. p. 63. 
36. Khan MA. Muheet-e-Azam. Vol. 1. New Delhi: Central Council for Research in Unani Medicine Publication; 1886. p. 751-4.

37. Ibn Sina BA. Al-Qanoon-Fit-Tib. (Urdu Translation by Ghulam Husain Kantoori). Vol. 2. Pakistan: Nigarshat Publishers; 1898. p. 152.

38. Ali SS. Unani Advia Mufrada. $5^{\text {th }}$ ed. New Delhi: National Council for Promotion of Urdu Language; 1989. p. 76.

39. Hubal I. Kitab-al-Mukhtarat Fit Tib. Vol. 2. Hyderabad: Darul Ma'arif Al Islamias; 1943. p. 130.

40. Israili AM. Tarjuma-e-Aqsaraie. Vol. 1. Lucknow: Munshi Nawal Kishore; 1907. p. 803.

41. Lubhaya GR. Bayanul Advia. Vol. 1. New Delhi: Goswami Kutub Khana; 1984. p. 50.

42. Chopra RN, Chopra IC, Handa KL, Kapur LD. Indigenous Drugs of India. Kolkata: Academic Publishers; 1958. p. 134.

43. Nadkarni KM. Indian Materia Medica. Vol. 1. Bombay: Popular Prakashan; 1976. p. 670.

44. Kirtikar KR, Basu BD. Indian Medicinal Plants. Vol. 2. Dehradun: International Book Distribution; 1987. p. 1440.

45. Ambasta SP. The Useful Plants of India. New Delhi: Publication and Information Directorate, CSIR; 1986. p. 280.

46. Dey KL, Bahadur R, Mair W. Indigenous Drugs of India. New Delhi: Pama Primalane, The Chronia Botanica; 1973. p. 160

47. Li R, Reed DW, Liu E, Nowak J, Pelcher LE, Page JE, et al. Functional genomic analysis of alkaloid biosynthesis in Hyoscyamus niger reveals a cytochrome P450 involved in littorine rearrangement. Chem Biol 2006;13:513-20.

48. Bernhoft A. A brief review on bioactive compounds in plants. In: Bioactive Compounds in Plants-Benefits and Risks for Man and Animals. Oslo: Proceedings from a Symposium Held at the Norwegian Academy of Science and Letters; 2010.

49. Begum S, Sahai M, Sussmuth R, Asai T, Hara N, Fujimoto Y. Hyosgerin (I), a new optically active coumarinolignan, from the seeds of Hyoscyamus niger. Chem Pharm Bull 2006;54:538-41.

50. Ma CY, Liu WK, Che CT. The flowering hormones. Ber Dtsch Bot Ges 2002;57:29-48.

51. Begum S, Saxena B, Goyal M, Ranjan R, Joshi VB, Rao CV, et al. Study of anti-inflammatory, analgesic and antipyretic activities of seeds of Hyoscyamus niger and isolation of a new coumarinolignan. Fitoterapia 2010;81:178-84.

52. Benhouda A, Yahia M. Toxicity, analgesic and anti-pyretic activities of methanolic extract from Hyoscyamus albus leaves in albinos rats. Planta Med 1999;65:60-3.

53. Massinissa Y, Affaf H, Mouloud Y. Analgesic, toxicity and anti-pyretic activities of methanolic extract from Hyoscyamus albus leaves in albinos rats. Int J Biotechnol Bioeng 2014;1:72.

54. Kiasalari Z, Khalili M, Khoshnevisan F. Evaluation of the effect of hydro-alcoholic extract of henbane seed on acute and chronic pain in male rats. Koomesh 2007;8:239-46.

55. Moradi M, Ghosian MH, Poor YE. Assessment of Hyoscyamus niger seeds alcoholic extract effects on acute and chronic pain in male NMRI rats. J Basic Clin Pathophysiol 2012;1:29-36.

56. Oto G, Ozdemir H, Yaren B, Yetkin Y, Tas A, Öztürk F, et al. Antinociceptive activity of methanol extract of Hyoscyamus reticulatus L. in mice. Am J Phytomed Clin Ther 2013;1:117-23.

57. Khan A, Gilani AH. In vivo studies on the bronchodilatory and analgesic activities of Hyoscyamus niger and Aspalathus linearis. Lat Am J Pharm 2010;29:777-82.

58. Kadi K, Yahia A, Hamli S, Auidane L, Khabthane H, Ali WK. In vitro antibacterial activity and phytochemical analysis of white henbane treated by phytohormones. Pak J Biol Sci 2013;16:984-90.

59. Ma CY, Liu WK, Che CT. Lignanamides and nonalkaloidal components of Hyoscyamus niger seeds. J Nat Prod 2002;65:206-9.

60. Reza HM, Mohammad H, Golnaz E, Gholamreza S. Effect of methanolic extract of Hyoscymus niger L. on the seizure induced by picritoxin in mice. Pak J Pharm Sci 2009;22:308-12.

61. Kiasalari Z, Khalili M, Heidari H, Azizi Y. Anti-convulsant effect of alcoholic Hyoscyamus niger L seed extract on PTZ model of kindling in male mice. Razi J Med Sci 2011;18:27-33.

62. Patil AD, Patil AY, Raje AA. Antidepressant like property of Hyoscyamus niger Linn. in mouse model of depression. Innov Pharm Pharmacother 2013;1:60-9.

63. Bourebaba L, Saci S, Touguit D, Gali L, Terkmane S, Oukil N, et al. Evaluation of antidiabetic effect of total calystegines extracted from Hyoscyamus albus. Biomed Pharmacother 2016;82:337-44.

64. Benhouda A, Yahia M, Khadhraoui H, Benbia S, Benhouda D. Hypoglycemic activity of methanolic extract of Hyoscyamus albus L. leaves in straptozotocin induced diabetic rats. Nat Prod Chem Res 2014;2:5.

65. Gilani AH, Khan AU, Raoof M, Ghayur MN, Siddiqui BS, Vohra W, et al. Gastrointestinal, selective airways and urinary bladder relaxant effects of Hyoscyamus niger are mediated through dual blockade of muscarinic receptors and Ca2+ channels. Fundam Clin Pharmacol 2008;22:87-99.

66. Khan AU, Gilani AH. Cardiovascular inhibitory effects of Hyoscyamus niger. Methods Find Exp Clin Pharmacol 2008;30:295-300.

67. Mohammad MK, Almasri IM, Tawaha K, Issa A, Al-NadafA, Hudaib M, et al. Antioxidant, antihyperuricemic and xanthine oxidase inhibitory activities of Hyoscyamus reticulatus. Pharm Biol 2010;48:1376-83.

68. Bustanji Y, Hudaib M, Tawaha K, Mohammad MK, Almasri I, Hamed $\mathrm{S}$, et al. In vitro xanthine oxidase inhibition by selected Jordanian medicinal plants. Jordan J Pharm Sci 2011;4:49-56.

69. Benhouda A, Yahia M, Benhouda D, Bousnane NE, Benbia S, Hannachi NE, et al. Antimicrobial and antioxidant activities of various extracts of Hyoscyamus albus L. and Umbilicus rupestris L. leaves. Algerian J Nat Prod 2014;2:4-17.

70. Alghazeer R, El-Saltani H, Saleh N, Al-Najjar A, Hebail F. Antioxidant and antimicrobial properties of five medicinal Libyan plants extracts. Nat Sci 2012;4:324-35

71. Dulger G, Dulger B. Antimicrobial activity of the seeds of Hyoscyamus niger L. (Henbane) on microorganisms isolated from urinary tract infections. J Med Plants Stud 2015;3:92-5.

72. Akhtar MS, GiII SA. Evaluation of anticlostridial efficacy of indigenous medicinal plant drugs: Rasoot, ajwain khurasani neem and bakain. Pak J Agric Sci 1992;29:371-5

73. Mateen A, Tanveer Z, Janardhan K, Gupta VC. Screening and purification of antibacterial proteins and peptides from some of the medicinal plants seeds. Int J Pharm Bio Sci 2015;6:774-81.

74. Sengupta T, Vinayagam J, Nagashayana N, Gowda B, Jaisankar P, Mohanakumar KP. Antiparkinsonian effects of aqueous methanolic extract of Hyoscyamus niger seeds result from its monoamine oxidase inhibitory and hydroxyl radical scavenging potency. Neurochem Res 2011;36:177-86

75. Mobin M, Khan MN, Abbas ZK. Ecotype difference in bioactive constituents and in vitro antioxidant activities of some Saudi medicinal plants. Eur J Med Plants 2015;7:125-36.

76. Souri E, Amin G, Dehmobed-Sharifabadi A, Nazifi A, Farsam H. Antioxidative activity of sixty plants from Iran. Iran J Pharm Res 2004;3:55-9

77. Hajipoor K, Sani AM, Mohammadi A. In vitro antioxidant activity and phenolic profile of Hyoscyamus niger. Int J Biol Pharm Allied Sci 2015;4:4882-90.

78. Gunes E, Zengin G, Uysal A, Aktumsek A, Durak Y. A study on antioxidant and antimicrobial properties of hexane and water extracts from Hyoscyamus reticulates. SUFEFD 2014;39:21-9.

79. Khatri DK, Juvekar AR. Propensity of Hyoscyamus niger seeds methanolic extract to allay stereotaxically rotenone-induced Parkinson's disease symptoms in rats. Orient Pharm Exp Med 2015;15:327-39.

80. Vallabi DE, Elango V. Preliminary studies on cardio protective effect of Hyoscyamus niger Linn in male albino rats. J Chem Pharm Res 2016;8:860-4.

81. Behravan M, Kakhki MR, Baharshahi A. Comparing larvicidal effect of methanol extract of the aerial parts of henbane (Hyoscyamus niger L.) and oleander (Nerium oleander L.) plants on Anopheles spp larvae (Diptera: Culicidae) in vitro. Zahedan J Res Med Sci 2017;19:e8631.

82. Daneshvar S, Mirhossaini ME, Balali-Mood M. Hyoscyamus poisoning in Mashhad. Toxicon 1992;30:501.

83. Craig OI. Emergencies in general practice: Poisons children swallow. Emerg Gener Pract 1975;17:1495-8.

84. Graev M, Fallani M. Collective poisoning caused by ingestion of Hyoscyamus niger (with a fatal case). Minerva Medicoleg 1960;80:225-30.

85. Tugrul L. Abuse of henbane by children in Turkey. Bull Narc 1985;37:75-8.

86. Anonymous. National Formulary of Unani Medicine, Part-I, Vol. I, New Delhi: Department of Ayurveda, Yoga and Naturopathy, Unani, Siddha and Homoeopathy (AYUSH), Ministry of Health and Family Welfare, Government of India; 2006. p. 9, 19, 35, 41-2, 88, 154-5, 239.

87. Anonymous. National Formulary of Unani Medicine. Part-II, Vol. 1. New Delhi: Department of Ayurveda, Yoga \& Naturopathy, Unani, Siddha and Homoeopathy (AYUSH), Ministry of Health \& Family Welfare, Government of India; 2007. p. 17,21,23-24,30-31,68,75,92-93.

88. Anonymous. National Formulary of Unani Medicine. Part-III, Vol. 1. New Delhi: Department of Ayurveda, Yoga \& Naturopathy, Unani, Siddha and Homoeopathy (AYUSH), Ministry of Health \& Family Welfare, Government of India; 2001. p. 21,31-32,83.

89. Anonymous. National Formulary of Unani Medicine. Part-IV, Vol. 1. New Delhi: Department of Ayurveda, Yoga \& Naturopathy, Unani, Siddha and Homoeopathy (AYUSH), Ministry of Health \& Family Welfare, Government of India; 2006. p. 108. 